\title{
Aeromagnetic Data Modeling for Geological and Structural Mappings over the DJADOM-ETA Area, in the Southeastern Cameroon
}

\author{
Justine Yandjimain ${ }^{1}$, Théophile Ndougsa-Mbarga ${ }^{1,2^{*}}$, Marcelin Bikoro Bi-Alou ${ }^{3}$, \\ Arsène Meying ${ }^{4}$ \\ ${ }^{1}$ Postgraduate School of Sciences, Technologies \& Geosciences, University of Yaoundé I, Yaoundé, Cameroon \\ ${ }^{2}$ Department of Physics, Advanced Teacher's Training College, University of Yaoundé I, Yaoundé, Cameroon \\ ${ }^{3}$ Department of Earth Sciences, Faculty of University of Maroua, Maroua, Cameroon \\ ${ }^{4}$ Department of Applied Geophysics, Geology and Mining Exploitation College, University of Ngaoundéré, \\ Ngaoundéré, Cameroon \\ Email:*tndougsa@yahoo.fr
}

How to cite this paper: Yandjimain, J., Ndougsa-Mbarga, T., Bi-Alou, M.B. and Meying, A. (2018) Aeromagnetic Data Modeling for Geological and Structural Mappings over the DJADOM-ETA Area, in the Southeastern Cameroon. International Journal of Geosciences, 9, 354-370.

https://doi.org/10.4236/ijg.2018.96022

Received: March 29, 2018

Accepted: June 23, 2018

Published: June 26, 2018

Copyright $\odot 2018$ by authors and Scientific Research Publishing Inc. This work is licensed under the Creative Commons Attribution International License (CC BY 4.0).

http://creativecommons.org/licenses/by/4.0/

\section{Open Access}

\begin{abstract}
The DJADOM-ETA area is in south-eastern of Cameroon, within the Congo Craton (CC) formations and composed of gneiss and amphibolite, migmatites and intrusive rocks. Few geophysical studies have been carried out over surrounding areas, but no investigation on the study area. The existence of aeromagnetic data covering the study area has motivated the application of a multiscale approach for tectonic features identification. The aim of this work is to interpret Aeromagnetic Data for Geological and Structural Mappings in the southeastern Cameroon. The GIS and GEOSOFT v8.4 softwares are used to treat data of Compagnie Minière du Cameroun getting in February 2012. The Tilt Angle method is used to delineate geological structures and to estimate the depth. The Euler's Deconvolution method is used to estimate the specific depth of structural contacts. The presence of bifurcations, accompanied by virgations, leading to the occurrence of several faults. Principal lineaments are determined with the main direction being ESE-WNW and E-W for the minor lineaments. The study highlights two major faults: ESE-WNW and ENE-WSW, where the former dominates, what could be called the geological accident of ETA. The Euler's Correlation and Tilt derivative contact map shows that most of the faults are vertical contacts. The geometrical description of this structure suggests an open synclinal transposed on vertical foliations: the major fault at the DJADOM axis is quasi-parallel to the Northern limit of the CC and parallel to the Sanaga Fault (SF) and the Central Cameroon Shear Zone (CCSZ). The features show a base strongly affected by tectonic which characterizes the transition between the zone from the $\mathrm{CC}$ and the belt from
\end{abstract}


folds of the Pan-African. Also, the presence of the network characterizes the subsurface undulation in this study area: the intrusion of sandstone ochre quartz and schist of the Bek complex, the dolerite of the doleritic complex, and the silver micaschiste and ore quartzite in the base complex. On the TMI anomalies map, several places show high susceptibility contrasts, which is an indication of strong magnetization. Geological indicators point to inferred magnetite, dolerite and ochre schist quartzite which have a strong magnetization in this zone. The presence of weakly magnetized anomalies would be due to the migmatites of the base complex series. This study improved the knowledge of the subsurface structure of this area. It highlighted two major and minor faults. TMI anomalies map, in several places shows high susceptibility contrasts, which is an indication of strong magnetization.

\section{Keywords}

Tilt-Angle, Euler Deconvolution, Lineaments, Djadom Fault

\section{Introduction}

Variations in the geomagnetic field are shown in aeromagnetic survey maps, in which magnetic anomalies are interpreted as being the result of fossilization of magnetic rocks. Thus, rocks exhibit the characteristics of magnetic fields. This observation is often explained using magnetic profiles and maps of magnetic lineaments [1]. Magnetic minerals can be mapped from the surface to greater depths in crustal rocks depending on the dimension, shape, and magnetic properties of the rock [2]. Cameroon is underlain by Precambrian rocks, Cretaceous sediments and Cenozoic sediments and volcanic formations [3]. Meso and Neoprotozoic rocks are found in the Southeastern part of the country. The Cameroon rock basement is divided into two units: the Congo Craton in the South and the Central African Mobile Zone (CAMZ) in the North. CAMZ is a domain of the Pan-African [4]. It consists of micaschist, plagioclase, bearing and micaceous gneisses, and migmatites intruded by quartz diorite and granodiorite. The study area is in the southern region of Cameroon (Central Africa). It is situated in the northern hemisphere, between the meridians $13^{\circ} 50^{\prime}$ and $14^{\circ} 20^{\prime}$ of longitudes East and parallels $2^{\circ} 10^{\prime}$ and $2^{\circ} 35^{\prime}$ of latitudes North, with an average altitude of $850 \mathrm{~m}$. In a geoelectrical study carried out to the north of this region, it is showed that the intense activities of gold washers encountered in the studied area do attest to the presence of clay mineral concentrations [5] [6]. To the east of this study area, recent geophysical study [7] has underlined the major network of lineaments identified in the area under study, which extend from SW to NE with an ENE-WSW major trend and can also be connected to those identified NE-SW by [8]. The aim of this work was to interpret aeromagnetic data for geological and structural mappings in the southeastern Cameroon. This study also focused on the determination of certain mineral resources potential in the area.

Cameroon is a part of CAMZ, with a geological basement of sedimentary 
rock. These sedimentary rocks are restricted to the southwestern and northern part of the country. In southwest Cameroon, the oldest sedimentary rocks are massive cross-bedded sandstones and conglomerates [9]. The sandstones are overlained by fossiliferous shales of early upper Cretaceous series ages [9]. The geological mapping of the study area (Figure 1) was first done by [9]. The investigated area lied in the southern part of Cameroon, is covered by Neoproterozoic formations and includes rocks resulting from the intermediate series, made up of schist and quartzite formed following an epizonal metamorphism [9] [10]. [10] considered the Ayos, Mbalmayo and Bengbis formations as being of a Precambrian mean age. The area is also included in the Dja inferior series and is comprised of the tillitic, doleritic and Bek complexes. It belongs indeed to the meta-sediments series of Dja-Ayos-Mbalmayo-Bengbis [11]. The geology of the area is dominated by the extension of the Archean Congo craton (Ntem Complex $\sim 3 \mathrm{Ga}$ ). The composition is made up of chlorite-greenschist, mica-schist with muscovite, and the lentilles of quartzite interstratifies. The doleritic complex (sills and dykes) is composed of greenschist, the mylonitics of quartzites, the dolerites and the gabbros. The Bek complex is made up of sandstones of quartzite ochre, clay-schist and blue schist. The base complex series of garnet is mainly composed of ectinites (gneiss and amphibolite), migmatites (granite of magmatic) and intrusive rocks (granite and granodiorite). The study area is a part of the Congo Craton (CC). Its formation dates to the rejuvenation during the Pan-African orogeny about $550 \mathrm{Ma}$ [3] [12] [13]. That major tectonic features lie under geological covers. Geophysical studies show that the boundary of the CC and the Pan-African is around $4^{\circ} \mathrm{N}$ [14] [15] [16]. An aeromagnetic study done by [17], estimates the northern boundary of the Congo Craton as starting from $3^{\circ} 7^{\prime} \mathrm{N}$ of West to $3^{\circ} 75^{\prime} \mathrm{N}$ of East. Its depth is estimated around 2.6 $\mathrm{km}$ for deep and $0.1 \mathrm{~km}$ for shallow while the direction is ENE-WSW and the $\mathrm{NW}$ slope varies from $30^{\circ}$ to $60^{\circ}$. Also, an audio-magnetotelluric study carried

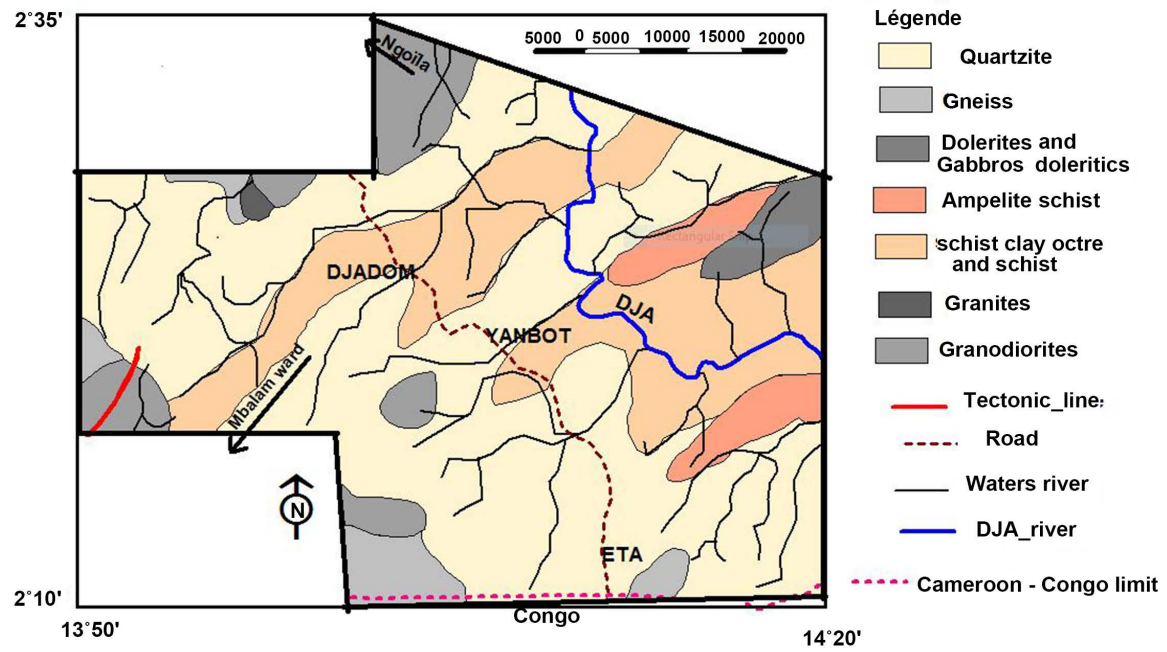

Figure 1. Geology map (modified). 
out by [16] shows many discontinuities in the topography of the subsurface. This topography presents a major deep-seated fault with E-W direction. Also, [7] showed the morphological difference and the tectonically subdivision into two tectonic sectors corresponding to the Congo Craton in the south, Pan-African in the north and helped identify the tectonic boundary separating them at depth. The tectonic features (faults and folds) are fitted into the CAFB's deformation history and could be due to the Trans-Saharan east-west collision system [18]. Some buried faults have been confirmed in geophysical studies [16] [19]. The Archaean metamorphic rock assembly has an E-W trending foliation $\left(\mathrm{S}_{1}\right)$ and intrusions that are usually aligned along a NE-SW trending foliation $\left(\mathrm{S}_{2}\right)$. The $\mathrm{S}_{1}$ foliation has near vertical dips to the north and is locally deformed into mesoscopic isoclinal $D_{2}$ folds. The $S_{2}$ foliation is a regional, steeply dipping planar fabric with variably oriented stretching lineation and large-scale open folds that are associated with $\mathrm{N}-\mathrm{S}$ trending sinistral and dextral strike-slip faults and mylonitic $\left(\mathrm{S}_{3}\right)$ foliation. The $\mathrm{S}_{2}$ foliation is well observed in the greenstone units of the Ntem complex and its development is linked to dome-and-basin tectonics related to diapiric movements [18].

\section{Materials and Methods}

\subsection{Data Source and Acquisition}

The aeromagnetic data set used in this study was from the recent acquisition by the Compagnie Minière du Cameroun SA (CMC SA) on 2012. Airborne geophysics with $200 \mathrm{~m}$ line spacing was conducted on Upper Nyong Division of the East Region of Cameroon in February 2012. The Survey was carried out by an AS350B2 helicopter, with a total of $11^{\circ} 305$ lines $\mathrm{km}$ of magnetic data and the flight was NE-SW trending. The survey was carried out at a nominal terrain clearance of $100 \mathrm{~m}$ which was monitored by a radar altimeter with an accuracy of $\pm 20 \mathrm{~m}$.

\subsection{Methodology}

\subsubsection{Total Magnetic Intensity Reduction to the Equator and Its Residual Anomaly}

After extraction, the aeromagnetic data survey was corrected and controlled on Excel. The anomaly of the total magnetic field (TMI), $\Delta B$ is the difference between the magnetic field extracted $B_{o b s}$ International Geomagnetic Reference Field (IGRF) $B_{\text {Ref }}$ to each station at the date February 15, 2012. This magnetic anomaly is given by (1):

$$
\Delta B=B_{o b s}+B_{R e f}
$$

The TMI map was reduced to the equator (RTE) (2) to avoid the problems associated with low-latitude magnetic data [20]. RTE is a complementary filter to the Reduction-to-Pole (RTP) procedure. Any magnetic anomaly point depends on the inclination and the declination of the main magnetic field of the earth. 
It transforms an anomaly of non-zero inclination into an anomaly that would be observed on the same body with zero inclination. The RTE can be expressed as:

$$
R T E=\sin I+i \cos I \sin (D-\theta)^{2}
$$

where $I$ is the geomagnetic inclination, $D$ is the geomagnetic declination, $\sin I$ is the amplitude component, and $i \cos I \sin (D-\theta)^{2}$ is the phase component.

The software Geosoft of Oasis Montaj v.8.4 using the convolution of Fourier transformation made it possible to obtain the map of TMI reduced to the equator and other relevant maps. To realize this map, this computed the values of the Inclination (I) and the Declination (D). These values are: $\mathrm{I}=-22.77^{\circ}$ and $\mathrm{D}=$ $-1.08^{\circ}$ respectively.

The residual anomaly ( $\left.\left[M_{R T E}\right]_{\text {residual }}\right)$ is calculated in each point of the regular grid by taking the difference between the anomaly of TMI RTE ( $\left.\left[M_{R T E}\right]\right)$ and Upward Continue to TMI RTE at $2 \mathrm{~km}$ ([ $\left.\left.M_{R T E}\right]_{U p 2 k m}\right)$. It is given by (3):

$$
\left[M_{R T E}\right]_{\text {residual }}=\left[M_{R T E}\right]-\left[M_{R T E}\right]_{U p 2 k m}
$$

\subsubsection{Tilt Angle Approach}

Also known as Variation of inclination, the tilt angle is a transformation which includes the first vertical derivative and the module of the first horizontal derivative of the anomaly of residual TMI reduced to the equator. The advantage of the tilt angle is that, compared with the other methods, it does not require the knowledge of parameters such as (density, magnetic susceptibility, structural index etc.). The other advantages of this transformation of the tilt angle are that, by computing an angle, all the forms are represented in a similar way; such that the anomaly either has minimum or maximum amplitude and that it also allows mapping the features with high resolution. Indeed, the arc-tangent function has as effect, to distribute the signal calculated between $-90^{\circ}$ and $+90^{\circ}$. The tilt angle applied to the anomaly of the magnetic field reduced to the equator permits to estimate the depth of the upper end of the sources. According to some authors [21] [22] [23], it is given by (4):

$$
\theta=\tan ^{-1}\left(\frac{\partial M / \partial z}{\partial M / \partial h}\right)
$$

where $\frac{\partial M}{\partial h}=\sqrt{\left(\frac{\partial M}{\partial x}\right)^{2}+\left(\frac{\partial M}{\partial y}\right)^{2}}$. Putting $H=\frac{\partial M}{\partial z} \quad$ and $Z_{c}=\frac{\partial M}{\partial h}$, then $\theta=\tan ^{-1}\left(\frac{H}{Z_{c}}\right)$. Thus $\theta=0^{\circ}$ for $H=0$ and $\theta= \pm \frac{\pi}{4}$ for $H= \pm Z_{C}$.

In other words, the estimated depth of the upper end of the source is obtained by measuring the perpendicular distance between contours $\theta=0 \mathrm{rad}$ and $\theta= \pm \frac{\pi}{4} \mathrm{rad}$ to the feature. The map of tilt angle is obtained by using the software Geosoft of Oasis Montaj v.8.4. This transformed map presents a correlation 
(or analogy) with the geological structure of the basement in this study area with a description of the zones of contact of the geological formations.

\subsubsection{Euler Deconvolution Approach}

Euler deconvolution [2] [24] is a method of estimating the depth and slopes of subsurface magnetic anomalies and can be applied to any homogeneous field of magnetic data [25]. In Euler's method, the structural index must be assumed as prior information because the quality of the depth estimation depends mainly on the choice of the proper structural index, which is a function of the geometry of the causative bodies and characterizes the rate of the variation of the anomaly intensity with a distance. Some authors [24] [26] showed that the optimum structural index usually yields the tightest clustering of the solutions. The depth estimates from magnetic data are more accurate with the equator-reduced magnetic field. The estimated Euler sources for the single-points are based on computing Euler's homogeneity Equation (4) and result in clusters used to constrain the overall geometry of the model. The 3D form of Euler's Equation (5) can be defined [27] as:

$$
\left(x-x_{o}\right) \frac{\partial F}{\partial x}+\left(y-y_{o}\right) \frac{\partial F}{\partial y}+\left(z-z_{o}\right) \frac{\partial F}{\partial z}=N(B-F)
$$

where $B$ is the regional value of the total magnetic field and $\left(x_{0}, y_{0}, z_{0}\right)$ is the position of the magnetic source, which produces the total magnetic field $\mathrm{F}$ measured at $(x, y, z) . \mathrm{N}$ is the Structural Index on how to characterize the source.

Therefore, it has assigned a value of 1.0 as a structural index to locate the possible magnetic contacts because it is particularly good at delineating the subsurface contacts. An overlapping moving window is $10 \mathrm{~km}$ by $10 \mathrm{~km}$, a tolerance of $10 \%$ for Euler residual field and 15\% for Euler Tilt angle and a proportioned symbol base of 100 .

\section{Results \& Discussion}

\subsection{Anomaly of Total Magnetic Intensity in the Studied Area}

The total magnetic field (TMI) is the response produced by rocks containing magnetic minerals. In Figure 2(a) \& Figure 2(b), the TMI anomalies are shown as $2 \mathrm{D}$ and $3 \mathrm{D}$ maps, varying from $-495.7 \mathrm{nT}$ to $93.7 \mathrm{nT}$ and are distributed in a bipolar way on the study area. The correlation between the TMI anomalies map and geological contacts is weak. The magnetic bandings which leads to magnetic bifurcation and a quasi-horizontal gradient at YANBOT are notices. On either side of the DJADOM and ETA axes, present the quasi-vertical gradient. At certain place, appear peak in the strongly magnetics formations. These observations underline the intense activities between the $\mathrm{CC}$ and the Pan-African. The DJADOM axis shows a lateral extension and longitudinal heterogeneous anomalies dominated by the positive anomalies, with a maximal value of $93.7 \mathrm{nT}$ and a long wavelength of $33176.9 \mathrm{~m}$. 


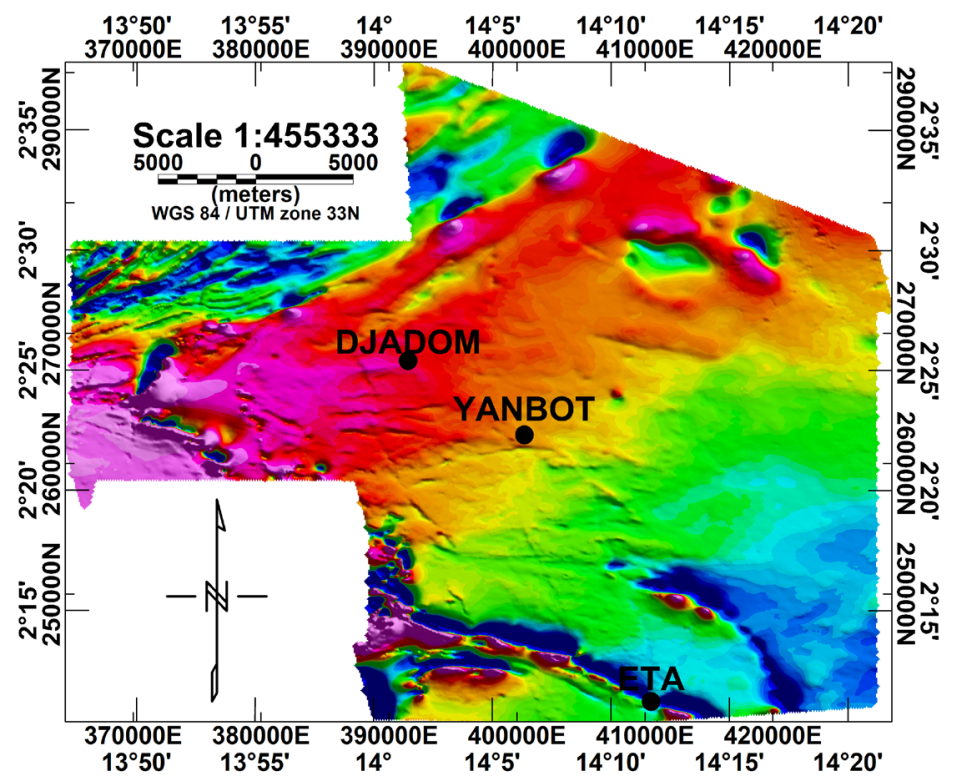

93.7

(a)

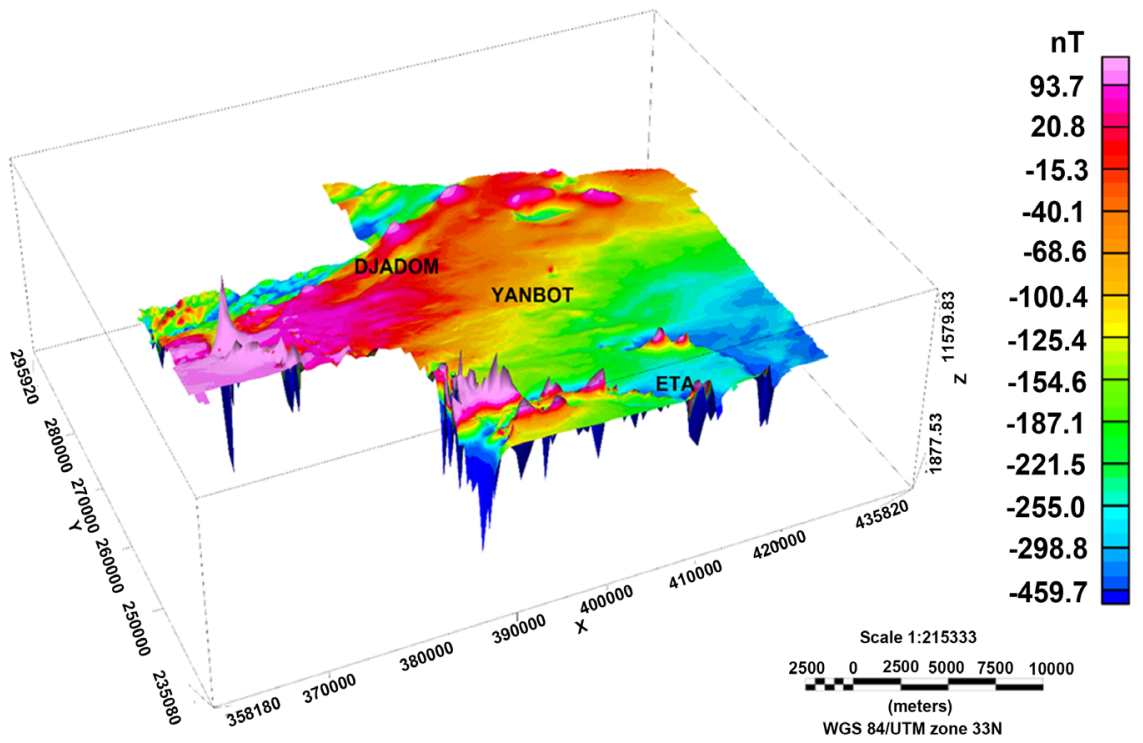

(b)

Figure 2. (a) Anomaly map of total magnetic Intensity of the study area. (b) Three-dimension Anomaly of total magnetic intensity map of the study area with even color bar.

Geologically, the preceding observations are due to sandstone ochre quartz and the schist of the Bek complex, the dolerite of the doleritic complex, and the silver micaschist and ore quartzite in the base complex. On the TMI anomalies map, several places show high susceptibility contrasts, which is an indication of strong magnetization. Geological indicators point to inferred magnetite, dolerite and ochre schist quartzite which have a strong magnetization in this zone. The presence of weakly magnetized anomalies would be due to the migmatites of the base complex series. 


\subsection{Anomaly Total Magnetic Intensity Map Reduced to Equator}

The anomaly total magnetic intensity map reduced to equator (TMI-RTE) in Figure 3 shows the anomalies varying from -465.8 to $134.5 \mathrm{nT}$. Compared to the TMI, the anomalies preserve their forms. Positive anomalies show the response of a strongly magnetized base. The longer-wavelength anomalies reflect deeper magnetic responses, whereas shortest-wavelength anomalies cause shallow magnetic responses [28]. The greater the wavelength, the deeper the response. These features characterize the earlier mentioned geological formations. The positive anomalies in the ESE-WNW and ENE-WSW directions tend to increase in amplitude and wavelength. The earlier mentioned gradients and the peaks are noticed here. These observations highlight the event of subduction of the CC onto the Pan-African.

The strong circular anomalies in this zone show the presence of accumulated minerals of strong susceptibilities in the major faults. This is due to the presence on the one hand of diamagnetic minerals such as ochre quartz and on the other hand, ferromagnetic minerals of strong magnetization remnants such as the ectinites, dolerites in the series of the basic complex and even magnetite.

\subsection{Total Magnetic Intensity Residual of the Study Area}

The values of the anomalies vary from $-204 \mathrm{nT}$ to $+121.7 \mathrm{nT}$, with a $12.8 \mathrm{nT}$ reduction compared to the total field RTE. The map of residual anomaly in Figure 4 shows the inferred magnetic bodies. The effects of the surface structures are masked by those of the underlying structures. The magnetic anomalies of the DJADOM axis have disappeared. The distributions of these anomalies are more refined and indicate the local maxima of the ESE-WNW and ENE-WSW directions as previously noted on the map of the TMI and its transforms. This

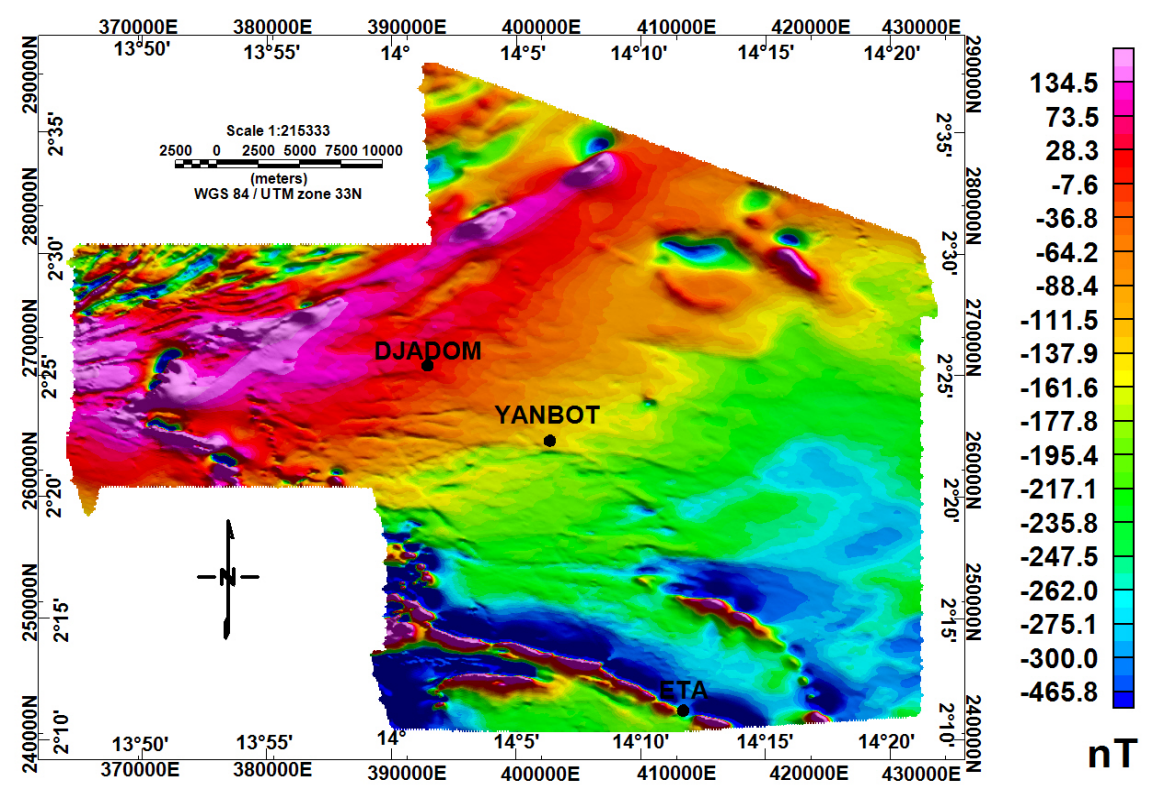

Figure 3. Anomaly map Reduced to Equator of the total magnetic intensity of the study area. 


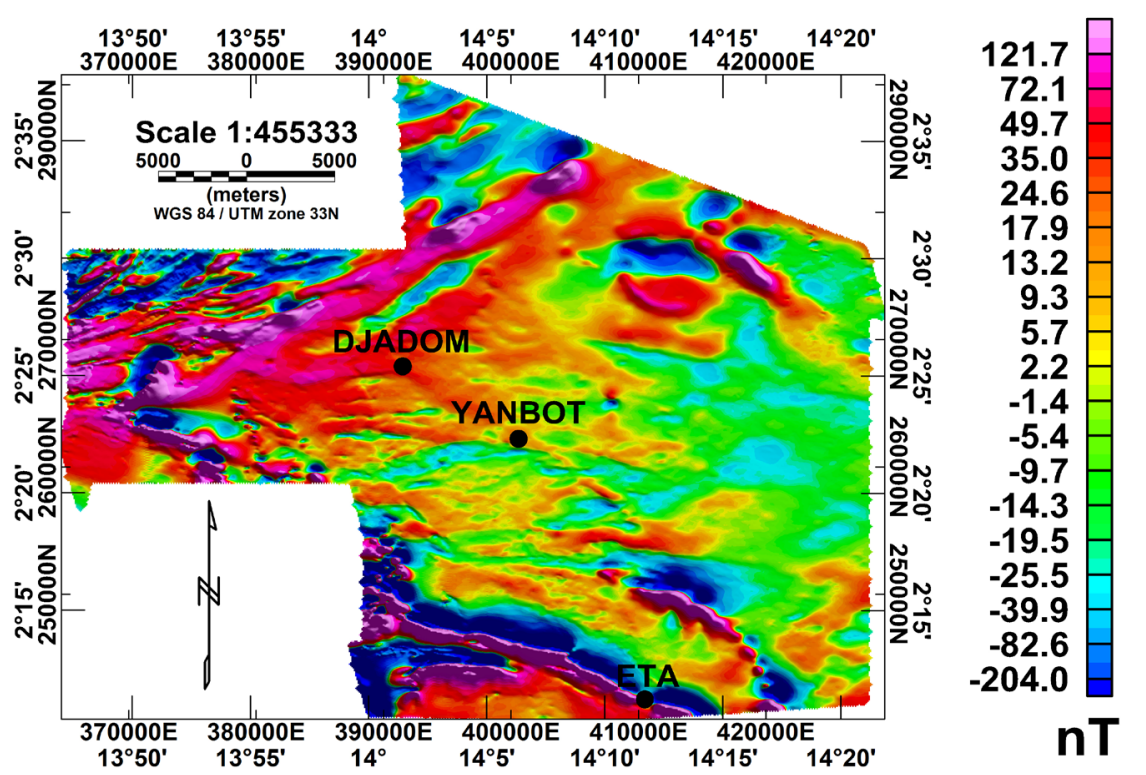

Figure 4. Anomaly of the residual Total magnetic intensity map of the study area.

orientation of positive anomalies makes it possible to identify the directions of major structures and to locate them. The magnetic peaks and the bandings are observed to burst and break in several areas, and these reflect the distribution of magnetization from the top to the bottom soil. The observed magnetization could be attributed to the intrusion of banded iron, magnetite, dolerite, mylonitic quartzite with dolerite and amphibole in the northern part and to the area situated southwest of DJADOM, then BIF, schist and sandstone quartzite ochre, and diamond in the southern part. The opening formation accompanied by virgations to the southwest of DJADOM is remark, giving rise to two great geological undulations. Since the amplitudes and wavelengths are maximal, enable to say that the geological undulations go from the covers to the base.

The structural map leads to put in evidence a network of faults in the study area and thus to show that the network of faults in the adjacent Eastern zone of this area is prolonged into the current zone [7]. The continuity of this prolongation Northwards of this zone is highlighted in the audio-magnetotelluric [16] and in aeromagnetic [17] studies. The geometrical description of this structure suggests an open synclinal transposed on vertical foliations: the major fault at the DJADOM axis is quasi-parallel to the Northern limit of the CC and parallel to the Sanaga Fault (SF) and the Central Cameroon Shear Zone (CCSZ). The directions of the lineaments are show in Figure 9.

\subsection{Variation of Inclination Angles (Tilt Angle)}

The Tilt angle of the residual anomalies of TMI shown in Figure 5(a) and the amplitudes of the angles vary between $-1.4 \mathrm{rad}$ and $+1.3 \mathrm{rad}$ while the lengths also vary. The tilt angle reflects the surface and subsurface distribution of structural contacts. This map shows several features on the subsurface which are not visible on the geological map. The interpretation of the aeromagnetic data shows 


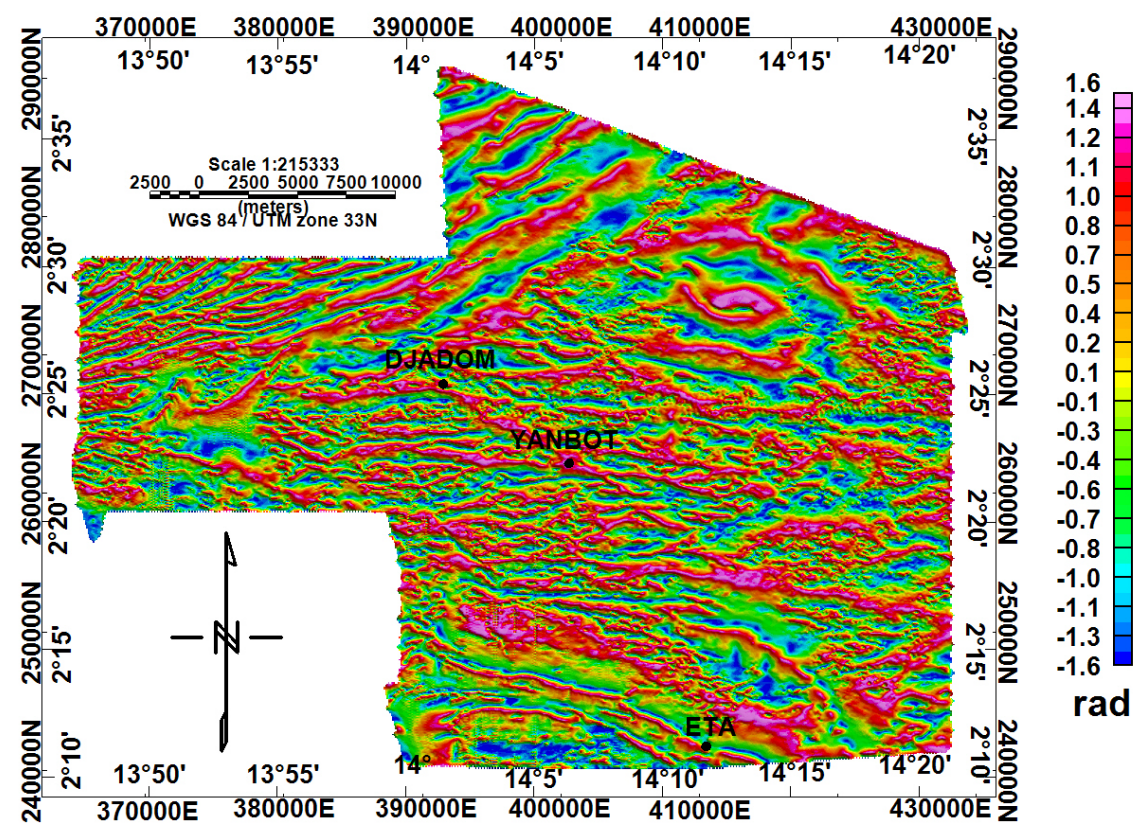

(a)

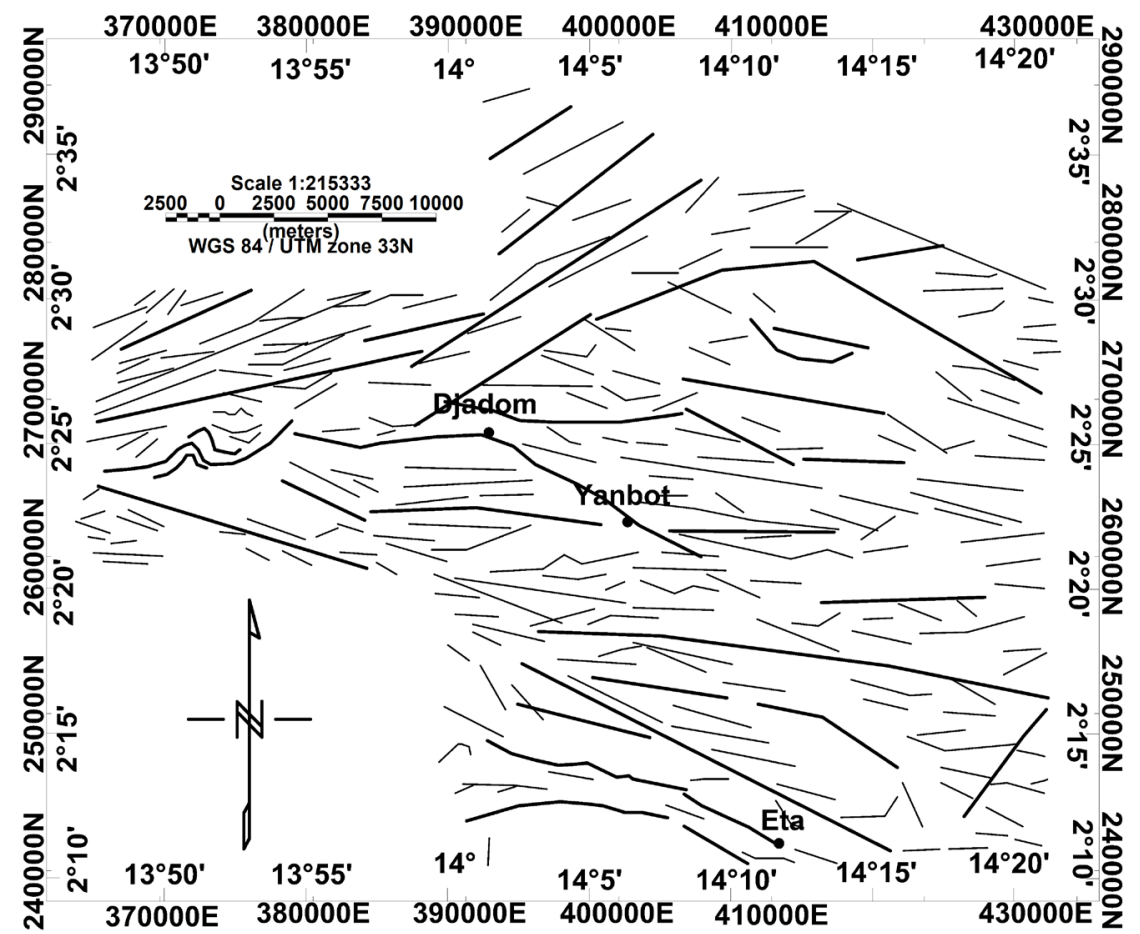

(b)

Figure 5. (a) Variation of magnetic inclination; (b) Lineaments of variation of magnetic inclination.

several magnetic features in this zone of study. The previous maps permitted us to observe Breakings. The positive magnetic anomalies are burst and laid out according to the features. The structures in the $\mathrm{E}-\mathrm{W}$ quasi direction meet a shock the southwest of DJADOM, and then start on a curve to take the ESE-WNW, E-W 
and ENE-WSW directions. This curve of the structural directions indicates a fold of drive, revealing a sinister movement following the WNW-ESE direction, and dextral in the SWS-NEN direction. These can be interpreted as fractures. In this zone where these fractures are more significant (DJADOM and ETA axes), notice the compartments with fractures. These zones of significant fractures are considered as delimiting significant features which refer to as the accident of the ETA for the ESE-WNW direction.

According to the amplitude and the length (Figure 5(b)), 39 major features and 397 minor features, making a total of 436 are noted. These principal features have lengths varying from $1731.9 \mathrm{~m}$ to $33176.9 \mathrm{~m}$, and depths going from $5.0 \mathrm{~m}$ to $238.8 \mathrm{~m}$. The characteristics (lengths, directions and depths) of the principal features are grouped in Table 1. The minor lineaments show that the base was affected by the tectonic events which characterize the transition between the zone from the Congo Craton and the belt from the folds of the Pan-African.Generally, foliations are of quasi-parallel texture. These foliations are controlled by Eburnean oogenesis and confirm those mentions by [29].

\subsection{Euler Deconvolution}

\subsubsection{Euler Deconvolution of Residual Field}

The Euler's solutions enable the characterization of magnetic responses and determination of the depth and geometry of intruding bodies [2]. The Euler's solution (Figure 6) has as structural index $\mathrm{N}=1$, tolerance $\mathrm{T}=10 \%$ and Nyquist Window $\mathrm{W}=10 \mathrm{~km} \times 10 \mathrm{~km}$. The depth of Euler's solution varies from $13 \mathrm{~m}$ to $314 \mathrm{~m}$, including those of the bodies with their geometries. The interpretation of the structural map highlights the various features affecting this study area. The deep features and the limit of the intrusive bodies are distinguished. The great directions of lineaments of this area are: NE-SW, ENE-WSW, E-W and

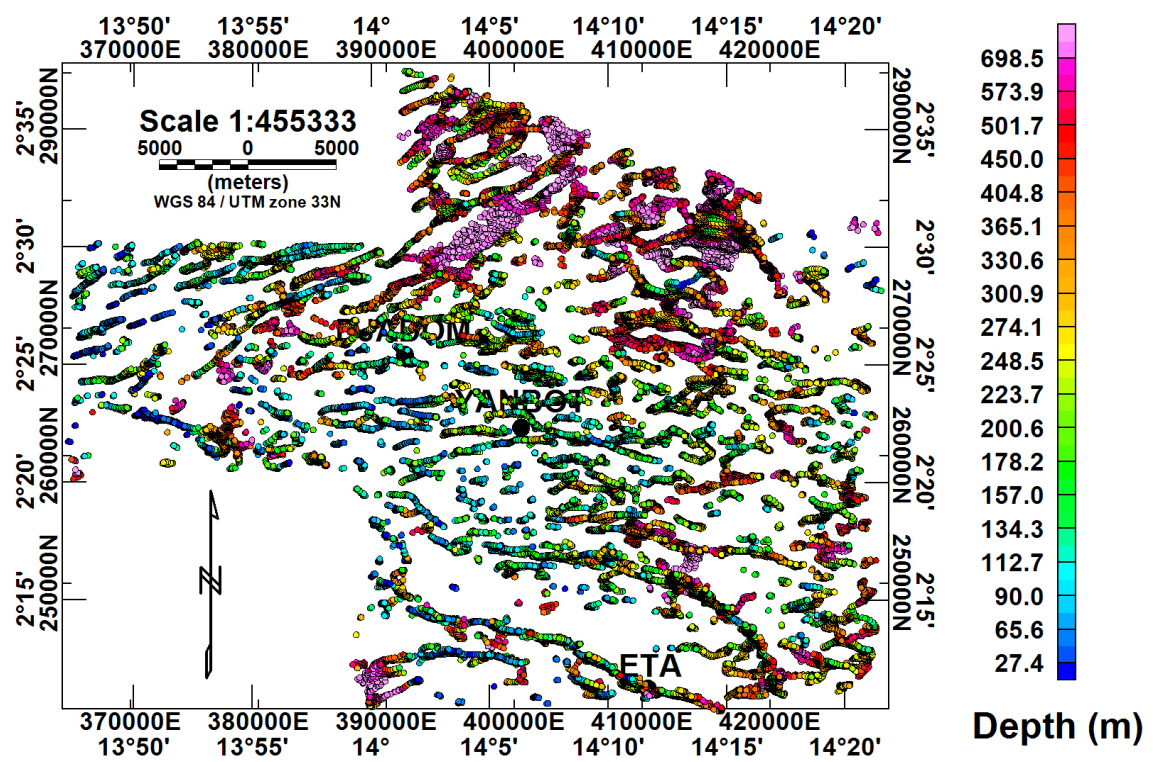

Figure 6. Euler's solution of TMI residual $\mathrm{N}=1, \mathrm{~T}=10 \%, \mathrm{~W}=10 \mathrm{~km} \times 10 \mathrm{~km}$. 
Table 1. Direction of major features, their lengths and their depths resulting from Tilt angle (depth 1), resulting from the Euler's solution of VMI (depth 2).

\begin{tabular}{|c|c|c|c|c|c|c|c|c|c|}
\hline $\mathrm{N}^{\circ}$ & $\begin{array}{c}\text { Direction } \\
\left({ }^{\circ}\right)\end{array}$ & $\begin{array}{l}\text { Length } \\
(\mathrm{m})\end{array}$ & $\begin{array}{l}\text { Depth } 1 \\
\text { (m) }\end{array}$ & $\begin{array}{l}\text { Depth } 2 \\
\text { (m) }\end{array}$ & $\mathrm{N}^{\circ}$ & $\begin{array}{c}\text { Direction } \\
\left({ }^{\circ}\right)\end{array}$ & $\begin{array}{l}\text { Length } \\
(\mathrm{m})\end{array}$ & $\begin{array}{l}\text { Depth } 1 \\
\text { (m) }\end{array}$ & Depth $2(\mathrm{~m})$ \\
\hline 1 & N104E & 33176.9 & 64.49 & $0.7-65.1$ & 21 & N87E & 7965.6 & 78.5 & $0.7-74.4$ \\
\hline 2 & N119E & 24462.3 & 237.2 & $2.5-237.3$ & 22 & N107E & 7965.6 & 223.43 & $2.5-109.8$ \\
\hline 3 & N69E & 23674.4 & 138.8 & $2.5-142.2$ & 23 & N102E & 9021.0 & 238.8 & $109.8-237.3$ \\
\hline 4 & N55E & 21949.7 & 223.9 & $0.7-237.3$ & 24 & N118E & 6988.8 & 87.8 & $2.5-109.8$ \\
\hline 5 & N80E & 19129.5 & 124.2 & $2.5-124.8$ & 25 & N94E & 9253.1 & 62.1 & $4.9-65.1$ \\
\hline 6 & N59E & 17165.9 & 100.1 & $2.5-109.8$ & 26 & N117E & 8763.2 & 83.3 & $14.2-164.4$ \\
\hline 7 & $\mathrm{~N} 76 \mathrm{E}$ & 14272.5 & 100.1 & $2.5-109.8$ & 27 & N107E & 7289.8 & 223.9 & $14.2-237.3$ \\
\hline 8 & N67E & 12699.4 & 237.8 & $31.0-237.3$ & 28 & N100E & 6245.5 & 17.8 & $0.7-14.2$ \\
\hline 9 & N54E & 12930.8 & 87.8 & $0.7-96.5$ & 29 & N101E & 5296.5 & 164.9 & $22.6-164.8$ \\
\hline 10 & N82E & 12010.5 & 220.9 & $74.4-237.3$ & 30 & $\mathrm{~N} 43 \mathrm{E}$ & 5322.5 & 237.2 & $2.5-237.3$ \\
\hline 11 & N118E & 10613.1 & 166.0 & $2.5-164.4$ & 31 & N80E & 5596.2 & 62.1 & $2.5-74.4$ \\
\hline 12 & N96E & 12762.6 & 222.1 & $22.6-237.3$ & 32 & N87E & 5056.8 & 220 & $14.2-237.2$ \\
\hline 13 & N115E & 10478.5 & 39.3 & $2.5-48.1$ & 33 & N103E & 4732.8 & 62.1 & $2.5-74.4$ \\
\hline 14 & N66E & 11192.3 & 5.0 & $0.7-4.9$ & 34 & N129E & 5005.4 & 228.9 & $48.1-237.3$ \\
\hline 15 & N71E & 8109.3 & 161.6 & $2.5-164.41$ & 35 & N225E & 6761.5 & 237.2 & $109.8-237.3$ \\
\hline 16 & N101E & 12206.8 & 237.2 & $109.8-237.3$ & 36 & N291E & 6144.4 & 17.1 & $0.7-14.2$ \\
\hline 17 & N90E & 9648.3 & 138.8 & $2.5-164.4$ & 37 & $\mathrm{~N} 270 \mathrm{E}$ & 2745.7 & 223.8 & $22.6-237.3$ \\
\hline 18 & N126E & 7586.5 & 149.5 & $2.5-164.4$ & 38 & N84E & 1731.9 & 223.8 & $22.6-237.3$ \\
\hline 19 & N141E & 9134.9 & 62.1 & $2.5-65.1$ & 39 & N56E & 2360.9 & 223.8 & $22.6-237.3$ \\
\hline 20 & $\mathrm{~N} 112 \mathrm{E}$ & 9812.3 & 237.2 & $84.9-237.3$ & & & & & \\
\hline
\end{tabular}

ESE-WNW. The important lineament, earlier referred to as the ETA geological accident is observed on this map. Their depths vary from $13.3 \mathrm{~m}$ to $313.1 \mathrm{~m}$.

\subsubsection{Euler Deconvolution Variation of the Inclination (Tilt Angle)}

Euler's solution shown in Figure 7 presents a depth varying from $0.7 \mathrm{~m}$ to 238 $\mathrm{m}$. More details on the depth of the intruding geological structures in the base are shown. The solution is used for the final interpretation of the geological contacts associated to the features noted previously. The extent of the number of structures on the map highlights the intense tectonic activity that this area undergoes. This is the reason of the metamorphism of the cover, renovated by the internal stress at the time of the collision.

Effectively, the series of solutions are observed which indicate the major fault at ETA. The depths of the structures in this map are proof of the fact that this study area belongs to the mobile zone of the central African mobile belt (CAMB) as stated in gravimetric investigations [19]. The quasi-discordance of contacts is confirmed by the disposition of Euler's solutions (Figure 6). 


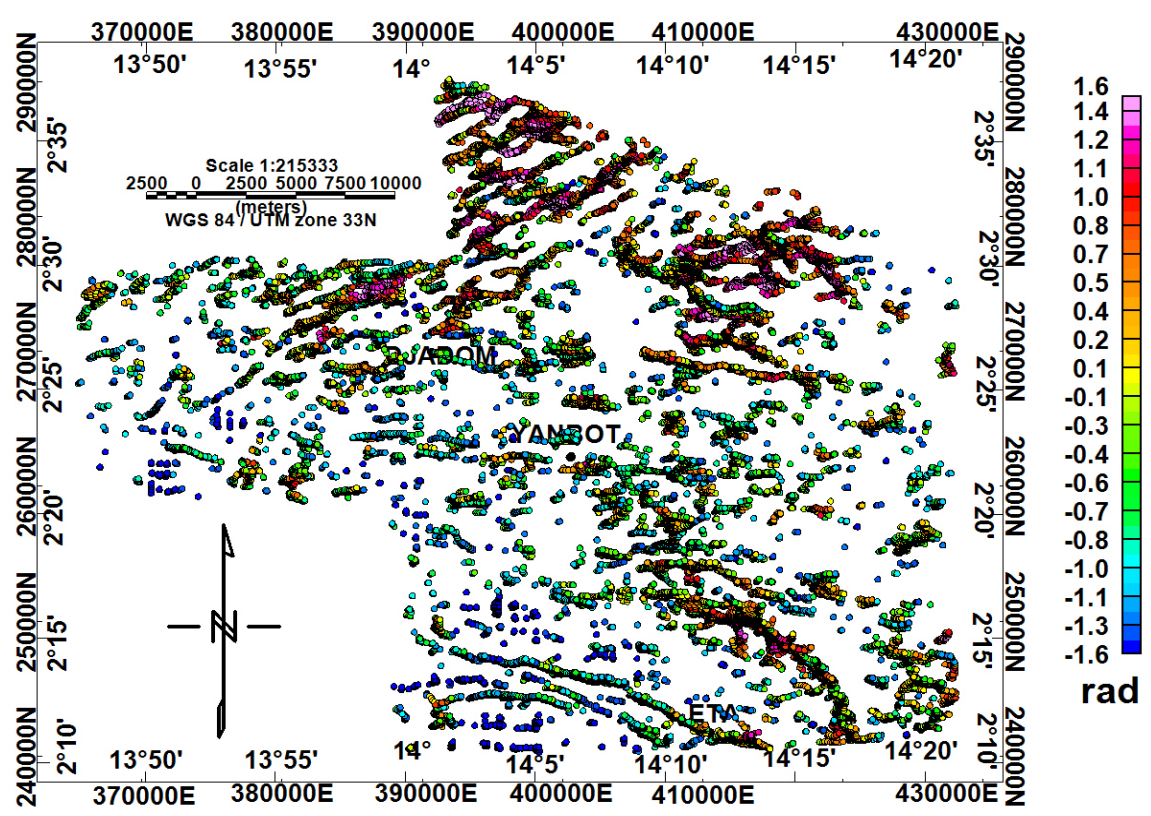

Figure 7. Euler's solution of VIM N =1, T $=15 \%, \mathrm{~W}=10 \mathrm{~km} \times 10 \mathrm{~km}$.

\subsection{Correlation of Tilt Angle Structures and Its Euler's Deconvolution Map}

The interpretation done by superimposing maps of tilt angle and Euler's is based on criteria elaborated by many authors [17] [24] [30] [31].

If the features of the Variation of the Magnetic Inclination (VMI) and those of the Euler solution are almost parallel and do not merge, the VMI features represent the contacts while those of Euler's solutions indicate the sense and direction of their slopes for these contacts and the overlapping of the ores located in these features.

If the features of the VMI and those of the Euler's solution are almost parallel and are merged, the VMI features represent the contacts while those of the Euler solution indicate the direction and sense for the vertical slopes of these contacts and the vertical gradients affecting the base.

The correlation map (Figure 8) shows the superposition of the features resulting from the VMI and the Euler's solutions which are almost parallel, and their slopes are like those obtained within the framework of the geological study. There are several principal lineaments with vertical contact. These slopes are dextral in the Center and South, and sinistral in the North.

\section{Conclusions}

The main results obtained in this study highlight new elements which enable the improvement of the knowledge on the structural features of the studied area. The tilt angle method is used to delineate geological contacts and structures and to estimate the depth and the length.

The bifurcation, accompanied with virgations, given the fact that there are many faults with WNW-ESE, W-E and WSW-ENE major directions. There is 


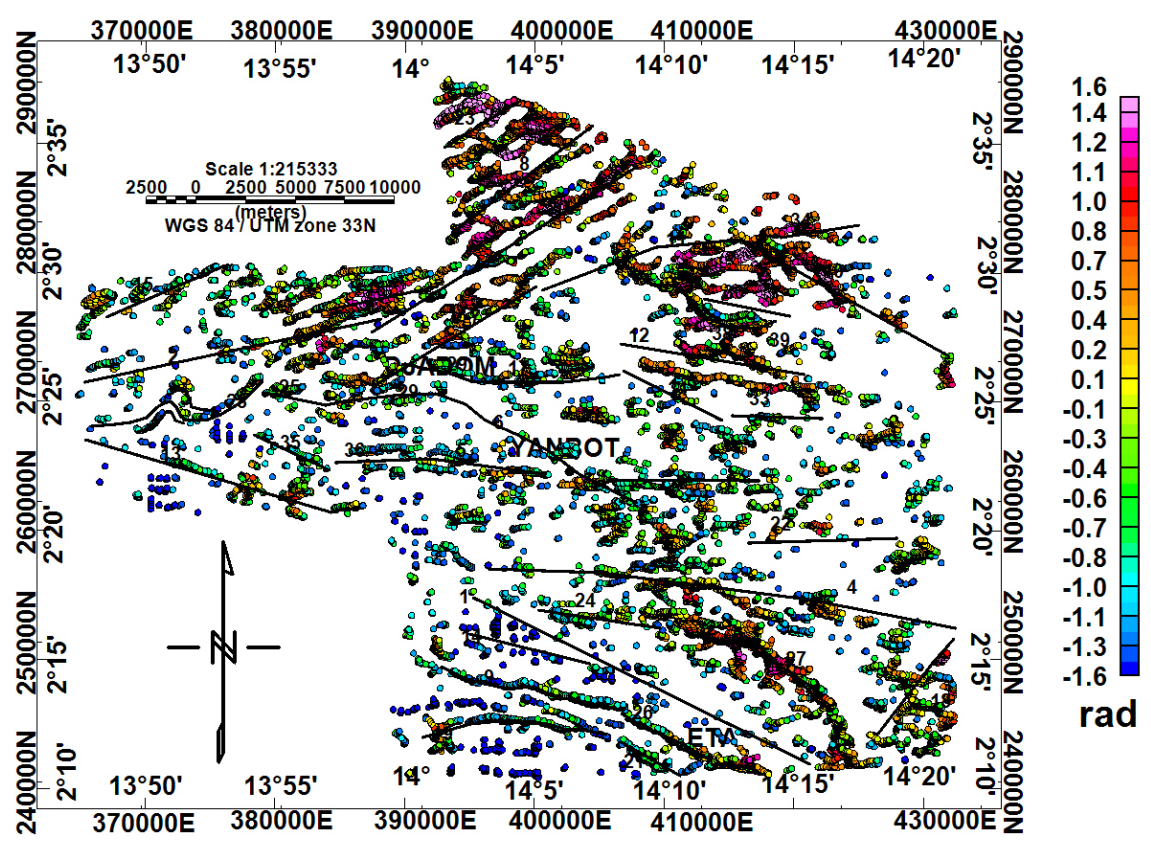

Figure 8. Euler's solution of VIM N =1, T $=15 \%, \mathrm{~W}=10 \mathrm{~km} \times 10 \mathrm{~km}$.

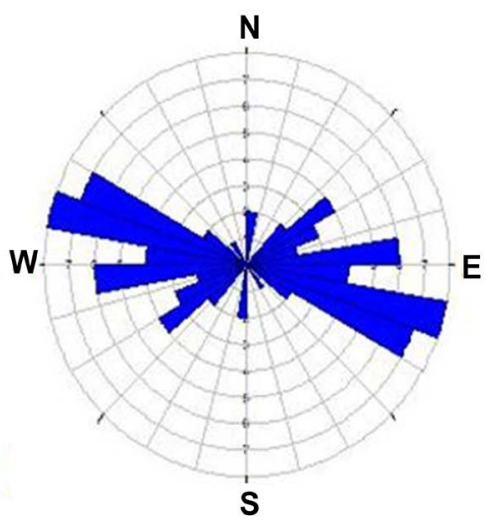

(a)

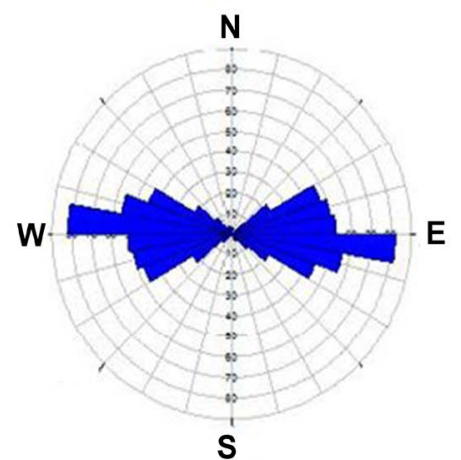

(b)

Figure 9. (a) Rosacea diagram of the major lineament orientations; (b) Rosacea diagram of the minor lineaments orientations.

a faulting system in this study area. Principal lineaments are determined with the major direction being WNW-ESE, while that for the minor lineaments is W-E (Figure 9). Two major faults ESE-WNW and ENE-WSW are highlighted with the dominant direction being ESE-WNW, which could be named the geological accident of ETA. This shows the series of deformations with a principal ESE-WNW direction under conditions which are realized in extreme cases of the metamorphic state, which according to have a rather recent deformation. This study enables a better knowledge of the subsurface structure of this area. The intrusion of dolerite, mylonitic quartzite of dolerite, magnetite, quartzite schist and sandstone quartzite of ochre are remarked. A geophysical exploration of this zone would enable us to better highlight the preceding observations. 


\section{Acknowledgements}

The authors are grateful to the reviewers and the readership for their kind help in making the manuscript clearer, more correct and mature for publication.

\section{Conflict of Interests}

The authors declare that there is no conflict of interests regarding the publication of this paper.

\section{References}

[1] Reeves, C. (2005) Aeromagnetic Surveys. Principales, Practice \& Interpretation. Earthworks, Global Thinking Exploration Geoscience. Geosoft, Toronto, ON.

[2] Gunn, P.J. and Dentih, M.C. (1997) Magnetic Response Associated with Mineral Deposits. AGSO Journal of Australian Geology \& Geophysics, 17, 145-158.

[3] Toteu, S.F., Penaye, J. and Poudjom Djomani, Y. (2004) Geodynamic Evolution of the Pan-African Belt in Central Africa with Special Reference to Cameroon. Canadian Journal of Earth Sciences, 41, 73-85. https://doi.org/10.1139/e03-079

[4] Vail, J.R. (1989) Ring Complexes and Related Rocks in Africa. Journal of African Earth Sciences, 8, 19-40. https://doi.org/10.1016/S0899-5362(89)80006-5

[5] Gouet, D.H., Meying, A., Assembe, S.P. and Ndougsa-Mbarga, T. (2013) Gold Mineralization Channels Identification in the Tindikala-Boutou Area (Eastern-Cameroon) Using Geoelectrical (DC \& IP) Methods: A Case Study. International Journal of Geosciences, 4, 643-655. https://doi.org/10.4236/ijg.2013.43059

[6] Gouet, D.H., Meying, A., Assemble, S.P. and Ndougsa-Mbarga, T. (2015) Clay Minerals Channels Identification in the Tindikala-Boutou Area (Eastern-Cameroon) along the Kadey River Using Direct Curent (DC) Method. Journal of Geoscience and Environment Protection, 3, 123-133. https://doi.org/10.4236/gep.2015.36018

[7] Feumoe, A.N.S., Ndougsa-Mbarga, T., Manguelle-Dicoum, E. and Derek Fairhead, J. (2012) Delineation of Tectonic Lineaments Using Aeromagnetic Data for the South-East Cameroon Area. Geofizika, 29, 175-192.

[8] Shandini, N.Y., Tabord, C.T. and Fairhead, J.D. (2010) Gravity Data Interpretation in the Northern Edge of the Congo Craton, South-Cameroon. Anuário do Instituto de Geociências, 33, 73-82.

[9] Van Den Hende (1969) Notice Explicative sur la Région Batouri-Ouest Ouest de la Carte Géologique de Reconnaissance à l'échelle du 1/500.000, Direction des Mines et Géologie, Yaoundé, Cameroun, 23.

[10] Bessoles, B. and et Lasserre, M. (1977) Le complexe de base du Cameroun. Bulletin de la Société Géologique de France, 19, 1085-1092.

https://doi.org/10.2113/gssgfbull.S7-XIX.5.1085

[11] Paterson, Grant, Watson Ltd. (1976) Etudes aéromagnetiques sur certaines Régions de la République Unie du Cameroun. Rapport d'interprétation. ACDI, Toronto, Canada, 190.

[12] Djoukan F.M.L., Shüssler, U. and Tchouankoue, J.P. (2004) Geochemistry and Petrogenesis of Neoproterozoicgranitoids within the Central African Fold Belt in the Bafoussam Area, Western Cameroon (Central Africa). University of Wuerzburg, Germany, 4.

[13] Vicat, J.P. (1998) Esquisse géologique du Cameroun. Collection GEOCAM, Presses 
Universitaire Yaoundé, 3-11.

[14] Ndougsa-Mbarga, T., Yufenyiu Layu, D., Quentin Yene-Atangana, J. and Tabod C.T. (2014) Delineation of the Northern Limit of the Congo Craton Based on Spectral Analysis and 2.5D Modeling of Aeromagnetic Data in the Akonolinga-Mbama Area, Cameroon. Geofísica Internacional, 53, 5-16. https://doi.org/10.1016/S0016-7169(14)71486-2

[15] Tadjou, J.M., Nouayou, R., Kamguia, J., Kande, H.L. and Manguelle-Dicoum, E. (2009) Gravity Analysis of the Boundary between the Congo Craton and the Pan-African Belt of Cameroon. Austrian Journal of Earth Sciences, 102, 71-79.

[16] Meying, A., Ndougsa-Mbarga, T. and Manguelle-Dicoum, E. (2009) Evidence of Fractures from the Image of the Subsurface in the Akonolinga-Ayos Area (Cameroon) by Combining the Classical and the Bostick Approaches in the Interpretation of Audio-Magnetotelluric Data. Journal of Geology and Mining Research, 1, 159-171.

[17] Yandjimain, J., Ndougsa-Mbarga, T., Meying, A., Bi-Alou, M.B., Ngoumou, P.C., Assembe, S.P., Ngoh, J.D. and Owono-Amougou, O.U.I. (2017) Combination of Tilt-Angle and Euler Deconvolution Approaches to Determine Structural Features from Aeromagnetic Data Modeling over Akonolinga-Loum Area (Centre-East, Cameroon). International Journal of Geosciences, 8, 925-947.

https://doi.org/10.4236/ijg.2017.87053

[18] Mvondo, H., Owona, S., Mvondo-Ondoa, J. and Essono, J. (2007) Tectonic Evolution of the Yaoundé Segment of the Neoproterozoic Central African Orogenic Belt in Southern Cameroon. Canadian Journal of Earth Sciences, 44, 433-444. https://doi.org/10.1139/e06-107

[19] Ndougsa-Mbarga, T., Manguelle-Dicoum, E., Tabod, C.T. and Mbom-Abane, S. (2003) Modélisation d'anomalies gravimétriques dans la région de Mengueme-Akonolinga (Cameroun). Science, Technology and Development, 10, 64-74.

[20] Grauch, V.J.S., Bauer, P.W. and Kelson, K.I. (2004) Preliminary Interpretation of High-Resolution Aeromagnetic Data Collected near Taos, New Mexico. New Mexico Geological Society, Guidebook, 244-256.

[21] Salem, A., William, S., Fairhead, D., Ravat, D. and Smith, R. (2007) Tilt-Depth Method: A Simple Depth Estimation Method Using First-Order Magnetic Derivatives. The Leading-Edge December, Meter Reader, Vol. 150, 2-5.

[22] Verduzco, B., Fairhead, J.D., Green, C.M. and Mac-Kenzie, C. (2004) New Insights into Magnetic Derivatives for Structural Mapping. The Leading Edge, 23, 116-119. https://doi.org/10.1190/1.1651454

[23] Miller, H.G. and Singh, V. (1994) Potential Field Tilt a New Concept for Location of Potential Field Sources. Journal of Applied Geophysics, 32, 213-217. https://doi.org/10.1016/0926-9851(94)90022-1

[24] Reid, A.B., Allsop, J.M., Granser, H., Millett, A.J. and Somerton, I.W. (1990) Magnetic Interpretation in Three Dimensions Using Euler Deconvolution. Geophysics, 55, 80-90. https://doi.org/10.1190/1.1442774

[25] Durrheim, R.J. and Cooper, R.J. (1998) EULDEP: A Program for the Euler Deconvolution of Magnetic and Gravity Data. Computer and Geosciences, 24, 545-550. https://doi.org/10.1016/S0098-3004(98)00022-3

[26] Thompson, D.T. (1982) EULDEP: A New Technique for Making Computer-Assisted Depth Estimates from Magnetic Data. Geophysics, 47, 31-37. 
https://doi.org/10.1190/1.1441278

[27] Reid, A.B. and Thurston, J.B. (2014) The Structural Index in Gravity and Magneticinterpretation: Errors, Uses, and Abuses. Geophysics, 79, J61-J66.

[28] Langenheim, V.E. and Jachens, R.C. (2014) Aeromagnetic Data, Processing, and Maps of Fort Irwin and Vicinity, California. In: Buesch, D.C., Ed., Geology and Geophysics Applied to Groundwater Hydrology at Fort Irwin, U.S. Geological Survey Open-Fort Report 2013-1024, Chap. 1.

[29] Feumoé and Ndougsa-Mbarga (2017) Curie Point Depth Variations Derived from Aeromagnetic Data and the Thermal Structure of the Crust at the Zone of Continental Collision (South-East Cameroon). Geophysica, 52, 31-45.

[30] Ndougsa-Mbarga, T., Feumoe, A.N., Manguelle-Dicoum, E. and Derek-Faihead, J. (2012) Aeromagnetic Data Interpretation to Locate Buried Faults in South-East Cameroon. Geophysica, 48, 49-63.

[31] Phillips, J.D. (1998) Processing and Interpretation of Aeromagnetic Data for the Santa Cruz Basin-Patahonia Mountains Area, South-Central Arizona. U.S. Geological Survey Open-File Report, Arizona, 02-98. 